\title{
World and Russian fuel and energy market development perspectives and drivers
}

\author{
D. R. Peskova ${ }^{1}, J . P$. Vasileva ${ }^{2, *}, U$. A. Nazarova ${ }^{3}$, and Z. F. Sharifyanova ${ }^{4}$ \\ ${ }^{1}$ Financial University under the Government of the Russian Federation, Moscow, Russia \\ ${ }^{2}$ Ufa State Petroleum Technological University, Ufa, Russia \\ ${ }^{3}$ Educational Center for State Service of Employment of the Republic of Bashkortostan, Ufa, Russia \\ ${ }^{4}$ Financial University under the Government of the Russian Federation Ufa Branch, Ufa, Russia
}

\begin{abstract}
The fuel and energy sector of the world economy and of Russia in particular is surviving heavy and high-speed transformations which inevitably will touch everyone. This article aims to analyze the modern tendencies of Russian worldwide natural resources perspectives of development and to understand the potential of economic drivers. Therefore, the current picture of oil and gas market for Russia and others countries was evaluated. Possible risks for Russian Federation including entrepreneurial difficulties were studied. Using econometric methods, the features influencing the amount of oil extracting were defined. The research allowed us to conclude that the major significant variable influencing oil extraction is "Well yield per day". According to this result we may state the initiating of new oil fields is of great need in Russia.
\end{abstract}

\section{Introduction}

The fuel and energy resources are still very important for the well-being on the Earth. The economic development of all countries in the world possessing or not the natural resources depends on world oil prices, volumes of the energy commodities trade, their market speculations. The fuel and energy sector is surviving heavy and highspeed transformations which inevitably will touch everyone. These changes may affect the whole range of aspects from the way people will tank up their cars, heat houses, how the economy will be arranged [1]. The current tendencies of the energy sector development might have tremendous sequences for the companies, countries and individuals. Oil resources keep the positions of the basic energy source. Oil supply is: in Europe -9 years, Russia and Central Asia -23 years, the middle East -74 years, Africa -41 years, AsiaPacific - 17 years, North America - 34 years, Latin America - 91 years [2]. All fossil fuels in global energy supplies is approximately $80 \%$, and crude oil approximately 40.6 per cent of primary energy consumption [3]. The Organization of PetroleumExporting Countries (OPEC) experts forecast the oil to be the dominant to satisfy the energy need of the world economy until the 2040 and by the end of forecasting period oil resources will reach $52 \%$ of the world energy balance. By this time daily demand for petroleum will increase on $16,5 \%$ and exceed 111 bln of barrels. The major consumers for the fuel will be Chinese and Indian economies [4].

Let's take a closer look onto current directions of world fuel and energy sector development. In 2017-2018 the world economy has recovered the past economic crises.
As estimated the growth of world product in 2017 reached $3,8 \%$ against $3,2 \%$ in 2016, 3,7 in 2018 (Figure 1). Nevertheless, according to International Monetary Fund research (IMF) the world economic growth will slow down to 3,5 in 2019 [5]. Escalation of the tension in trade between USA and China, tightening of monetary policy and geopolitical challenges are the general issues which will provide economic stimulus decline in 2019.

Such dynamics was similar for the most countriesmembers of Organization for Economic Cooperation and Development (OECD) (excepting the Great Britain) and for the countries not membering OECD (except for India). The very important factor enhancing the ameliorating the world economy landscape has become the stabilization of world oil market. It leads to investment increase to the oil-producing countries but to the improvements of manufacturing and budgetary and taxation situation in these countries. In highly developed countries labor markets continuously improved. USA reached the situation of almost full employment by the end of the year. Japan hit the lowest unemployment as well. So did the Eurozone countries which reached the lowest level of unemployment since the beginning of 2007-2008 financial crisis [6].

The overall results of economic development in 2012-2017 for the Russian Federation turned out poorer in compare with other resource-based economies (except for Venezuela). The real GDP 2017 of Russia remained on the level of 2012 while the GDP of other resourcebased countries increased in average on $13 \%$ in 2013 2017 [7].

\footnotetext{
*Corresponding author: vasilevajulia@bk.ru
} 
During the period of 2017-2018 the solid growth of demand for oil was shown: in 2017 up to 97.01 MMBoe/d, in 2018 - up to $98.61 \mathrm{MMBoe} / \mathrm{d}$.

Upon estimations of the International Energy Agency (IEA), the 2017 world market oil deficit stated in average 0.46 MMBoe/d (against the surplus of 0.7 in 2016). During the year of 2017 the inventory over shortened from 340 to 74 MMB. In 2018 oil demand increase was driven by the significant extension of petroleum-chemical factories and stable economic activity in USA. Asian leaders for oil demand defined by oil products demand are India, Indonesia, Singapore and Thailand. In the Middle East the demand for oil weakened as a response to the economic reforms, including subsidy abolishment, replacement plans and energetic efficiency policy.

On the supply side, OPEC and non-OPEC countries supported extend of output cuts. The combination of stable demand and output cuts led to oil inventory stock decrease from 175 bln barrels in 2016 to normal level. As a result, Brent oil Brent inflated price approximately of $24 \%$ since 2016 , pricing up to $54.2 \mathrm{USD} / \mathrm{b}$ in 2017 [8].

In 2018 according to OPEC estimations petroleum supply increased by $2.50 \mathrm{MMBoe} / \mathrm{d}$. At the same time the overall supply from non-OPEC countries in 2018 reached $60.03 \mathrm{MMBoe} / \mathrm{d}$. These positive tendencies enhanced the development of fuel and energy sector in USA. They increase export of oil, natural gas and chemicals, significantly influencing world energy market.

The production of raw oil in 2017-2018 was 1102 576.1 thousand tons according to statistics of Ministry of Energy of Russia.

As resulted in 2018 the volume of internal production of raw oil increased versus the 2017 by 9.1 bln tons $(1.7 \%)$ and summed up to 555.9 bln tons. Over half of mentioned increase (5.0 bln tons, $13.5 \%$ ) was covered by newly opened oil deposits aged less than 5 years [9]. In addition, the Russian Federation possesses the third part of the world's explored natural gas reserves and is one of the main suppliers in the world markets [10].

The development of oil extracting industry and export of mineral resources provide the income for the major part of Russia's budget. For export goes 3/4 of Russian oil [11]. Though the results of resource industry are taken in account not as intermediate achievement but as basis for revival of subsistence production in whole [12].

At the moment the economic situation in Russia incurs multiple risks which affect the effectiveness and productivity of entrepreneurial activity in oil and gas industry [13]. It is necessary to manage risks, especially in conditions of additional digitalization [14]. We define the major factors of international level entrepreneurial risk as follow:

- forestalling growth of world market in compare with volumes of world production,

- labor decrease, while increase the amount of retired people in highly developed countries which will lead to GDP shrink,

- changes in basic powerholders in IMF,

- world oil prices dynamics.

Certainly all these factors influence Russian economy which at the moment is suffering significant difficulties, increase of entrepreneurial risks barrier the economic development nonetheless the huge natural resources such as major oil fields.

In modern conditions of natural resources stock decrease of different countries Russian has a chance to use the need in subsoil resources of other countries to restore the economy and minimize the existing entrepreneurial risks [15]. Thus the researches on petroleum production increase and improvement are of high interest.

Table 1. Initial data (2007-2017).

\begin{tabular}{|c|c|c|c|c|c|c|c|c|c|}
\hline 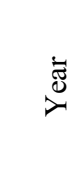 & 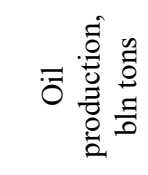 & 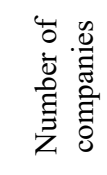 & 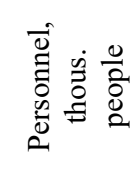 & 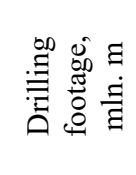 & 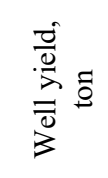 & 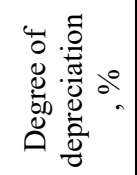 & 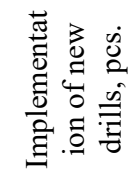 & 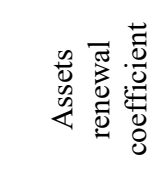 & 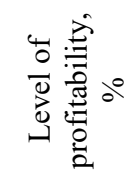 \\
\hline & $\mathrm{y}$ & $\mathrm{X}_{1}$ & $\mathrm{X}_{2}$ & $\mathrm{X}_{3}$ & $\mathrm{X}_{4}$ & $\mathrm{X}_{5}$ & $\mathrm{X}_{6}$ & $\mathrm{X}_{7}$ & $\mathrm{X}_{8}$ \\
\hline 2007 & 306.83 & 214 & 213 & 10.2 & 7.5 & 46.9 & 4198 & 3.4 & 21.2 \\
\hline 2008 & 301.23 & 273 & 246 & 6.9 & 7.4 & 48.3 & 2921 & 3 & 14.9 \\
\hline 2009 & 305.64 & 275 & 264 & 7.4 & 7.3 & 49.8 & 2390 & 1.6 & 14.7 \\
\hline 2010 & 303.28 & 385 & 289 & 5 & 7.7 & 52.1 & 2274 & 1.7 & 17.6 \\
\hline 2011 & 305.17 & 431 & 261 & 5.3 & 7.7 & 51.2 & 2081 & 1.7 & 57.9 \\
\hline 2012 & 323.52 & 439 & 267 & 9.3 & 7.5 & 53.3 & 2833 & 2.9 & 66.7 \\
\hline 2013 & 348.13 & 421 & 347 & 8.8 & 7.7 & 51 & 3813 & 4.2 & 46.5 \\
\hline 2014 & 379.56 & 436 & 331 & 8.6 & 8.3 & 53.9 & 3145 & 3.7 & 20.6 \\
\hline 2016 & 421.34 & 465 & 321 & 9.1 & 9.4 & 53.7 & 3004 & 4.1 & 20.7 \\
\hline 2017 & 459.21 & 637 & 293 & 8.3 & 10.1 & 53.1 & 3123 & 3.7 & 36.3 \\
\hline
\end{tabular}




\section{Methods}

To define the features influencing the amount of oil extracting the econometric method was implied. As the main indicator for our calculations was taken "Amount of oil production". Other factors are shown in the Table 1.

The calculation of variables in econometric models and estimation of significance were made using IBM SPSS Statistics 19 software.

\section{Results}

The research allowed us to conclude that the major significant variable influencing oil extraction is $\mathrm{X} 4$ Well yield per day. According to this result we may state the initiating of new oil fields is of great need in Russia. This requires more investments in petroleum industry.

\section{Discussion}

It should be mentioned. at the moment the methods of economic efficiency are estimation are underdeveloped. Nor does not exist reliable model. of state participation in investment projects of oil producing. Solving of these problems would significantly decrease the negative influence of risk factors onto the perspective development of oil and gas business in Russia.

\section{References}

[1] V.Ya. Ushakov, Isolyatsiya ustanovok v[1] The role of fuel and energy complex in development of national economy Oil and Gas engineering 2, 209-15 (1994)

[2] Yu. Vasiliyeva, G. Karachurina, Oil resources capacity and economic growth EuroAsian Law Journal vol 7(110), 309-11 (2017)

[3] Yu. Vasiliyeva, R. Salikhova, Oil market and economic growth in Russia Oil and Gas Engineering vol 2, 217-26 (2016)

[4] The official website of OPEC https://www.opec.org

[5] The official website of IMF https://www.imf.org

[6] Annual Report. Organization of the Petroleum Exporting Countries https://www.opec.org/opec web/static files_project/med ia/downloads/publications/AR\%202017.pdf (2017)

[7] B. Titov, Economic growth in the world and in Russia: "new normality" http://stolypin.institute/wpcontent/uploads/2018/02/issledovanie_novayanormalnost-2018.02.22.pdf (2018)

[8] World energy markets review: oil market / Research financial institute of Ministry of Finance of the Russian Federation. https://www.nifi.ru/images/FILES/NEWS/2018/energo 012018.pdf (2018)

[9] The official website of The Ministry of Energy of the Russian Federation https://minenergo.gov.ru
[10] D. Peskova, Yu. Vasiliyeva, T. Ponomareva, and N. Vavilova, Problems and perspectives of Russian gas export Problems of gathering. preparation and transport petroleum and oil products 1, 161-75 (2017)

[11] Yu. Vasiliyeva, D. Nasypova, Ponomareva, T. Sanction policy and development of oil industry Oil and Gas Engineering 3, 209-14 (2016)

[12] Yu. Vasileva, O. Shalina, G. Tokareva, E. Baykova, Integration and Clustering for Sustainable Economic Growth Springer International Publishing AG 537-51 (2017)

[13] D. Peskova, Yu. Khodkovskaya, R. Sharafutdinov, Digitalization of Business-processes in Oil and Gas Companies EuroAsian Law Journal, 9(124), 438-44 (2018)

[14] D. Peskova, Yu. Vasiliyeva, R. Sharafutdinov, Problems of Digitalization of Oil and Gas Businss EuroAsian Law Journal 4(131), 404-7 (2019)

[15] D. Peskova, Evseeva, «Sanctioned» development of Russian entrepreneurship Economy and Management: scientific and practical journal 3(125), 947 (2015) 